Riga Teacher Training and Educational Management Academy, Latvia

\title{
Encouragement of Pre-schoolers' Entrepreneurial Skills Development by Fundraising Activities and Play
}

\section{Abstract}

Modern world undergoes significant and continuous changes, therefore it is important to teach a child to think, search for unconventional solutions, learn to listen to the peers and adults, justify one's opinion, feel for the success and difficulties of other people, and take responsibility and risks from the very childhood.

The aim of the study is to assess theoretically and practically the use of fundraising activities and plays in preschool educational institutions in order to encourage the entrepreneurial development of children aged 5-6.

Materials and methods include analysis of pedagogical and psychologicalliterature, polling, organisation of actual fundraising activities and plays, and pedagogical observation.

In the teaching process in preschool educational institutions games and fundraising activities encourage the development of children's entrepreneurial skills fostering creative activities and improving speaking skills, initiative, at the same time reducing children's shyness, lack of confidence and indecision.

Children's communicative competence as well as entrepreneurial skills can be encouraged by adults on the basis of their observation of children's behaviour while at play. Adults can stimulate and support shy children, taking an active part in their games, helping them by setting an example, creating a suitable environment for games, devoting time to theatrical and role plays and inviting children to participate in fundraising activities.

Key words: entrepreneurial abilities, fundraising activities, plays, pre-schoolers

\section{Introduction}

We live in a complex age. What characterizes it is its rate, busyness, plenitude of information, efficiency and business transactions. It requires people who can communicate in various fields (entrepreneurship, politics, advertising, marketing, etc.), who can substantiate and stand up for their opinions, listen to those of other people, make a dialogue and be goal-oriented, independent and creative.

At present, under the circumstances of crisis and unemployment, the issue of encouraging entrepreneurship in Latvia and other countries of the European Union becames highly topical. Without an exception, we are all going through a period of economic and developmental challenges when we have to increase our competitiveness, master new technologies, seek for relevant solutions and 
at the same time maintain socially high and humane goals by looking for new opportunities for growth and introducing innovative solutions.

With a support from the programme "Central Baltic INTERREG IV A Programme 2007-2013", the project "Encouragement of the Development of Entrepreneurial Skills in Latvia, Estonia, Sweden and Finland" is being carried out in Latvia with several Latvian preschool educational institutions and schools taking part in it. The project covers issues concerning practical development of entrepreneurial education and skills on all levels of education.

When considering the concept of entrepreneurial skills, profesor V. Bikse (University of Latvia) gives the following definition in her research paper "The Progress of Latvia in the Educational Development Regarding Entrepreneurship After Joining of the European Union": "Entrepreneurial abilities or, in other words, entrepreneurial competence is an aggregate of personal abilities and qualities ensuring successful entrepreneurship. It includes: creativity and ability to introduce novelties, establish contacts, organisational and project management skills, abilities to take risks, initiative to put ideas into action" (Bikse, 2009).

According to the directives of the European Council, entrepreneurial abilities include personal qualities and attitudes, knowledge and skills regarding entrepreneurship necessary to establish a new enterprise and put the ideas into practice and develop them successfully. Entrepreneurial abilities (entrepreneurial competence) develop in the course of acquiring knowledge, skills and experience. It cannot be implemented by learning only a certain subject at school, for instance, social science or economics - it can only be done gradually, in a systemic and purposeful process of learning from the very childhood. No child is born with remarkable entrepreneurial skills; they are developed through vigorous action.

The aim of the study is to assess from theoretical and practical perspective fundraising activities and plays in preschool educational institutions for the encouragement of entrepreneurial development of children aged 5-6.

Materials and methods comprise an analysis of pedagogical and psychological literature, polling, organisation of actual fundraising activities and plays, and pedagogical observation.

\section{Encouragement of entrepreneurial skills of children aged 5-6 in fundraising activities and plays}

During preschool education, playing and games constitute the main type of children's activities (role plays, building games, theatrical plays). Children learn, speak, think, create, compose, observe and cooperate while playing (Dzintere, Stangaine, 2007). That is why games give a possibility to develop personal qualities that are necessary for the encouragement of entrepreneurial competence. 
Childhood is the most sensitive period in a person's life when the foundation for the individual disposition, self-confidence, value, communication and other systems is laid. To encourage entrepreneurial skills, it is necessary to stimulate the development of the following aspects of children's character from their early childhood:

- self-confidence;

- communication skills;

- creativity.

Games ensure children's holistic development. Children get to know themselves, explore the world and form an attitude towards it. Playing is in fact a complex inner process that is connected with children's thinking, imagination, fantasy, innovation. Children's activities with various objects play a highly significant role, and they are important not only for the child's intellectual development but also for fostering creative thinking, as indicated by J. Piaget (Piažē, 2002). By getting to know and exploring various objects children learn new things, and their previous knowledge is transformed by linking the existing experience with the new one. It encourages children's self-development as they are given an opportunity to foresee changes and various alterations of the objects through action.

The perception, introduction and formation of new ideas is a complex process as the new always alters the existing. J. Piaget calls it assimilation and accommodation of information (Piažè, 2002), whereas L. Vygotsky speaks of interiorisation and development of an inner action plan (Выготский, 1997). When playing (especially in role plays, building games and theatrical plays), children have to adjust new things to their existing experience. Ways for harmonising the prior and new experience and interconnections are sought for; new properties of the old become apparent allowing to use the idea or object differently than before (Dzintere, Stangaine, 2007).

A game is a creative processing of the experienced impressions. For children to be able to use not only their knowledge and experience but also form their attitude, an environment rich in impulses as well as children's own activities are necessary, emphasises J. Rodari (Rodari, 2009). Nevertheless, the adults' attitude towards children's game is a vital precondition for its development. Teachers as professionals who understand the importance of games and children's creative ideas, play a significant role in encouraging children's creativity. Studies and analysis of practical work show that in most cases the time devoted to free and independent play in preschool educational institutions (especially at the older preschool age) is fragmented. That is why children do not even attempt role plays or building games; instead they choose board games or just pointless running.

In order to improve the development of creativity, the following is necessary:

- prior experience, emotional experience;

- inner position, willingness to change the existing experience in the course of a game; 
- object environment encouraging children for action;

- playmates;

- free time for children's activities;

- support from adults.

In the innovation process children's initiative, liveliness and self-awareness are indispensable.

Self-confidence is one of the major factors that encourages children's development in the preschool period when they are most "open" to various influences. Children's "selves" - the nuclear of the personality - fosters their activities, the development of emotions, mind and willpower. Children's "selves" are fully manifested in games and activities freely chosen by themselves (Dzintere, Stangaine, 2007).

An analysis of pedagogical literature and practice shows it is playing that gives various opportunities for developing children's self-confidence (Dēkens, 1921; Students, 1935; Lieǵeniece, 1999; Romenkova, 1997). (See Figure 1)

\section{Figure 1. Play as an encouragement for children's self-confidence (Dzintere, Stangaine, 2007)}

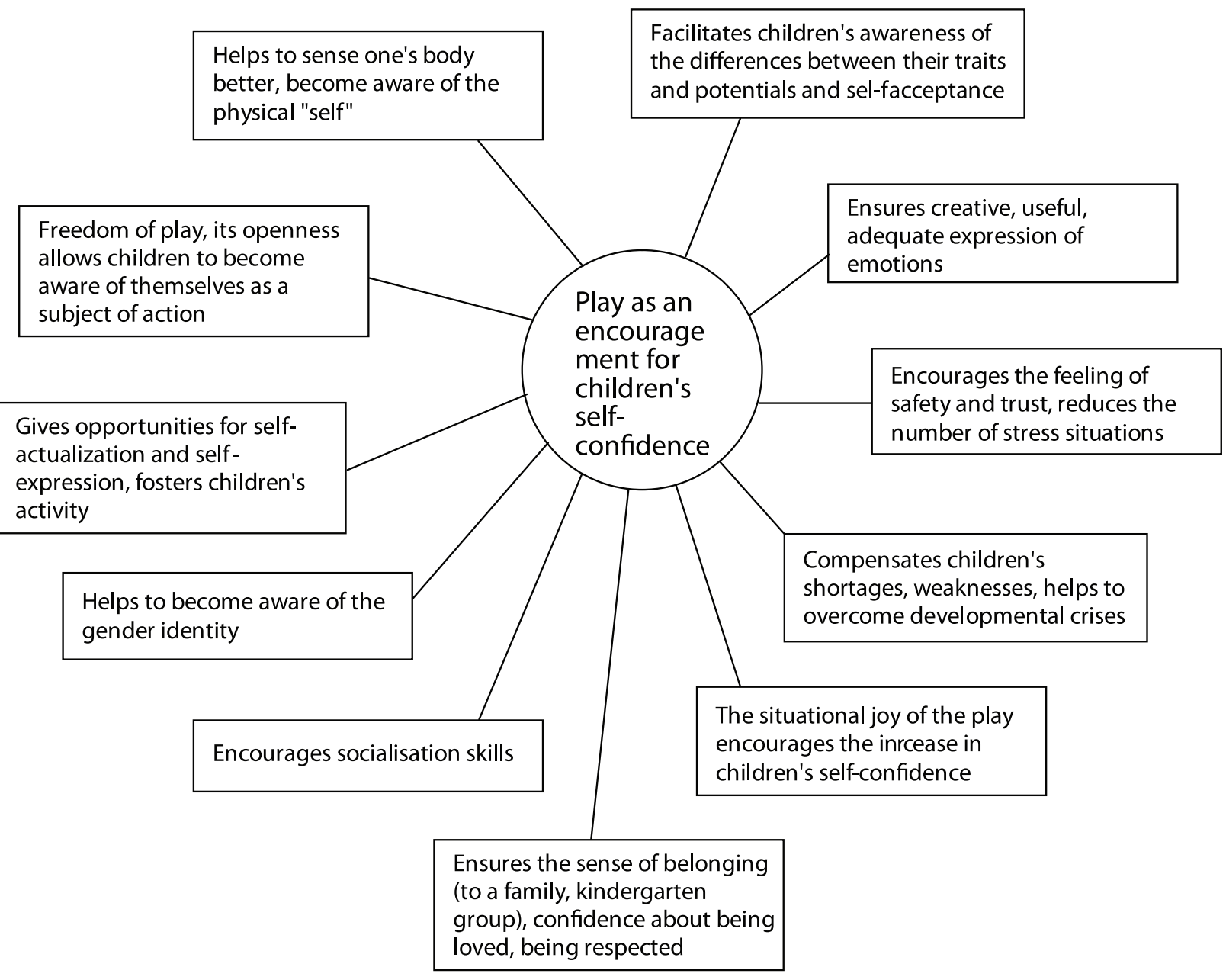




\section{Results}

In the course of history various types of play have developed. Each type has a considerable significance in children's psychic and social adaptation as well as the development of a holistic personality and self.

In the author's opinion, a precondition for the development of a play is the development of the child's self which is also the driving force in a play. Specific types of plays correspond to all stages of the development of self-confidence. Thus, playing and the development of self-confidence are interactive (see Table 1).

Table 1. Interaction between the development of self-confidence and play

\begin{tabular}{|c|c|c|}
\hline $\begin{array}{c}\text { Phases in the } \\
\text { development } \\
\text { of self- } \\
\text { confidence }\end{array}$ & $\begin{array}{c}\text { Play activities } \\
\text { encouraging the } \\
\text { development of self- } \\
\text { confidence } \\
\end{array}$ & Notes \\
\hline \multirow{4}{*}{$\begin{array}{l}\text { Identity } \\
\text { awareness, } \\
\text { getting to } \\
\text { know one's } \\
\text { own physical } \\
\text { self image }\end{array}$} & - Functional plays & $\begin{array}{l}\text { - children play with their own limbs, they } \\
\text { begin to become aware of their physical self }\end{array}$ \\
\hline & - Object manipulation & $\begin{array}{l}\text { - through a multitude of repetitions and } \\
\text { motor activities, children learn to integrate } \\
\text { activities of big and small muscles, in such } \\
\text { a way gaining control over the body (at the } \\
\text { age of } 0.6-2 \text { ) }\end{array}$ \\
\hline & - Destructive plays & $\begin{array}{l}\text { - children experiment, try out their skills, } \\
\text { become aware that they can cause an action } \\
\text { (at the age of } 0.6-2 \text { ) }\end{array}$ \\
\hline & - Movement plays & $\begin{array}{l}\text { - children run and jump enjoying the } \\
\text { possibility to express themselves in motion. } \\
\text { An increased movement coordination raises } \\
\text { self-confidence (from the age of } 1.5 \text { years). }\end{array}$ \\
\hline \multirow{2}{*}{$\begin{array}{l}\text { I-awareness of } \\
\text { the subject of } \\
\text { an action (what } \\
\text { I can, what I } \\
\text { want, what I } \\
\text { know) }\end{array}$} & - Joining plays & $\begin{array}{l}\text { - children copy scenes from the real world, } \\
\text { begin to understand roles and imaginary } \\
\text { actions, get to know themselves as subjects } \\
\text { of an action, assess their own capabilities (at } \\
\text { the age of } 2 \text { - 4) }\end{array}$ \\
\hline & - Building games & $\begin{array}{l}\text { - they depict what they have seen, build } \\
\text { houses, garages, etc. Children see the outer } \\
\text { world which they change according to their } \\
\text { imagination enjoying their success (at the } \\
\text { age of 3-6 and later) }\end{array}$ \\
\hline
\end{tabular}




\begin{tabular}{|l|l|l|}
\hline \multirow{2}{*}{$\begin{array}{l}\text { Becoming } \\
\text { aware of } \\
\text { their psychic } \\
\text { properties (I } \\
\text { am dexterous, } \\
\text { strong, } \\
\text { independent, } \\
\text { helpful) }\end{array}$} & $\begin{array}{l}\text { - Drama, symbolic, } \\
\text { creative games }\end{array}$ & $\begin{array}{l}\text { - a certain plot and roles appear in the game, } \\
\text { the experience is shown with the help of } \\
\text { symbols, language and objects (at the age of } \\
4-6 \text { and later) }\end{array}$ \\
\cline { 2 - 3 } & $\begin{array}{l}\text { - Commication or } \\
\text { Constructive games }\end{array}$ & $\begin{array}{l}\text { cooperation and competition, they } \\
\text { accept themselves, thus raising their self- } \\
\text { confidence: I am clever, witty, dexterous, I } \\
\text { can play with other children, meet my own } \\
\text { and their requirements (at the age of } 6 \text { and } \\
\text { later) }\end{array}$ \\
\cline { 2 - 3 } & $\begin{array}{l}\text { - children can create things of technical or } \\
\text { artistic value that depict reality; they enjoy } \\
\text { what they have achieved, including self- } \\
\text { regulation (at the age of } 6 \text { and later) }\end{array}$ \\
\hline
\end{tabular}

Children with low self-confidence require special tolerance and tact. They can be helped by emphasizing their good features of character; since every single child possesses some.

Children's self-confidence and entrepreneurial skills doubtless develop simultaneously through communication with adults as well as their peers. Psychologists L.Vygotsky (Выготский, 1997), J.Bruner (Брунер, 1987) and S. Omarova (Omarova, 1998) are of the opinion that communication with peers forms the basis for children's successful development and socialisation which is why children's ability to communicate and express their thoughts or suggestions is an effective means of communication.

Communication can be considered the main type of interaction. Ability to communicate includes the skill of conveying information and simultaneously getting it from a partner by listening, observing reactions and asking questions (Kraminšs, 2005).

Communicative competence is a system of inner means regulating communicative actions of a personality that encourage efficient interaction and are necessary to encourage entrepreneurial skills. One can assess children's communicative competence by observing whether they have mastered not only speaking skills (a common language) but also the ability to listen and cooperate with their playmates in the course of actual and imaginary game situations (Stangaine, 2010). That is why game has a significant role in the development of children's speech and encouragement of communicative competence. Psychologist J. Bruner says that it is through playing that children learn their native language within the context of practical activities, and that is the reason why imprecision of speech does not have unpleasant effect which is sometimes the case when it comes to learning 
at school. The scientist emphasises that the development of speech takes place not so much through language learning as through experimenting with language and children's own thinking (Брунер, 1987).

Children's communicative competence as well as entrepreneurial skills can be encouraged by adults on the basis of their observation of children's behaviour while at play. Adults can stimulate and support shy children, taking an active part in their games, helping them by setting an example, creating a suitable environment for games, devoting time to theatrical and role plays and inviting children to participate in fundraising activities.

When analysing various situations different interaction models can be singled out in communication that help in carrying out certain tasks (see Table 2).

Table 2. Analysis of communicative situations (Stangaine, 2010)

\begin{tabular}{|c|l|l|}
\hline $\begin{array}{c}\text { Combination } \\
\text { possibilities }\end{array}$ & \multicolumn{1}{|c|}{ Fulfilled tasks } & \multicolumn{1}{|c|}{ Explanation } \\
\hline $\begin{array}{c}\text { A child - an adult } \\
\mathrm{A} \leftrightarrow \mathrm{C}\end{array}$ & $\begin{array}{l}\text { Dialogic speech } \\
\text { Interaction } \\
\text { Emotions } \\
\text { A model for mirroring }\end{array}$ & $\begin{array}{l}\text { Enriches vocabulary, develops dialogic speech } \\
\text { techniques (to listen, to respond, to ask), } \\
\text { masters communication culture, learns to } \\
\text { express emotions in a socially accepted way. }\end{array}$ \\
\hline $\begin{array}{c}\text { A child - a toy } \\
\mathrm{A} \leftrightarrow \mathrm{T}\end{array}$ & $\begin{array}{l}\text { Monologic speech } \\
\text { Emotions } \\
\text { Imagination }\end{array}$ & $\begin{array}{l}\text { Looks for a mate to talk to, expresses emotions. } \\
\text { Indirectly prepares for a dialogue. Encourages } \\
\text { children's activity in a game: thinking, creativity, } \\
\text { initiative, independence }\end{array}$ \\
\hline $\begin{array}{c}\text { A child - a child } \\
\text { children) }\end{array}$ & $\begin{array}{l}\text { Dialogic speech } \\
\text { Self-confidence } \\
\text { Cooperation } \\
\text { Emotions } \\
\text { Positive outlook of } \\
\text { the world } \\
\text { Vocabulary }\end{array}$ & $\begin{array}{l}\text { Children experience various play situations, } \\
\text { enrich their vocabulary, learn to use the } \\
\text { language in various situations, role dialogues, } \\
\text { learn tolisten, hear the other person, harmonise } \\
\text { their own behaviour with that of the playmate, } \\
\text { learn to share. }\end{array}$ \\
\hline C
\end{tabular}

An empirical study on the encouragement of entrepreneurial skills of children aged 5-6 was carried out in Riga No 275 Preschool Educational Institution "Austrina" in the academic year of 2009/2010. A plan of activities was drawn up and pedagogical observations made. Teachers were asked to answer questions of a questionnaire about children's activities and encouragement of entrepreneurial skills.

3 groups of children of the preparatory age and 4 older groups of children participated in winter sports festival "Dwarf's House": in total, 135 children 
aged 5-6. The activity was supervised by preschool sports teachers S. Šidlovska and D. Kalnozola.

The aim of the event was to encourage the children to show initiative and be energetic in winter sports activities, as well as to give them a possibility to express themselves creatively in winter using the storyline of the Dwarf's travel.

The children in each group had prepared their own signs of distinction as advised by their teachers.

The results: through encouraging satisfaction about the achieved results, the children were given diplomas for active participation in the sports festival; the children showed their skills to be united and organised, they were friendly and helpful, and participated with great interest in building snow fortifications.

Another event - "Exhibition of self-made candles" was prepared thanks to the efforts of preschool education teachers who wanted to display candles made in various techniques.

The aim of the exhibition was to encourage skills how to put ideas into practice, how to be creative and active. The candle exhibition continued the entire month of February; little children who are not yet skilled in making complex things were especially welcome.

The results: the children were interested in making unusual and original candles, they tried to put themselves in younger children's shoes who are not yet so skilful, and were eager to give joy to everybody who attended the exhibition with a feeling of work well done.

A novelty in the agenda of the preschool educational institution was a fundraising event in Social Care Centre "Pārdaugava".

The aim of the event was to create a positive and emotional atmosphere by encouraging cooperation skills and inspiring the children to be creative and show their initiative.

All the children and their parents were involved in preparations for the event. The parents were asked to donate things they do not need any more but which might be useful for the inhabitants of the care centre "Pārdaugava". The parents' responsiveness was unexpectedly high.

The preschool education teachers made special gifts together with the children, like oat cookies and shortbread, greeting cards and other things.

Preschool education teachers A. Stoka, I. Šìmane and preschool education music teacher L. Everte prepared performances for children.

All the donated things were delivered to the Social Care Centre "Pārdaugava" during the fundraising event, and the gifts prepared by the children were presented to the inhabitants of the institution. Then the children played a theatrical game called "Old Man's Mitten". 
After the event the administration of the Social Care Centre "Pārdaugava" expressed a wish to continue cooperation with the preschool educational institution "Austrina".

The results: the children tried to understand daily chores of elderly people, they were happy to bring joy to someone else, give lavishly and gain satisfaction from a good job well done. Alongside with encouraging the joy of giving the development of children's craftsmanship as well as their skills of dialogic speech were stimulated.

\section{Festival of Great Day (Easter) in Social Care Centre "Pārdaugava"}

The aim of the event was to develop a sense of responsibility for peers, encourage getting acquainted with Latvian folk traditions and taking pride in wearing a national costume.

The participants of the event were music teachers M. Blāke and I. Malnača and 24 children aged 5-6: they recited Latvian folk songs, sang, danced and played musical instruments that gave true pleasure to the old people. At the end of the event the children left posters made by themselves to decorate the halls of the social care centre.

The results: the children showed their ability to express themselves, be decisive and creative, actively introduce themselves, address the audience and wear the Latvian folk costume proudly being aware that promises must be kept, that one must take responsibility for what has been promised.

During the empirical research the children were observed while playing; this allows us to draw conclusions regarding the development of entrepreneurial skills in relation to various games. See the results of observations in Table 3.

Table 3. Role of a game and play in encouraging entrepreneurial abilities

\begin{tabular}{|l|l|l|}
\hline \multicolumn{1}{|c|}{ Plays and games } & \multicolumn{1}{|c|}{$\begin{array}{c}\text { Characterisation of } \\
\text { entrepreneurial skills }\end{array}$} & \multicolumn{1}{c|}{ Role of adults } \\
\hline $\begin{array}{l}\text { Plays, board games, } \\
\text { developmental } \\
\text { games }\end{array}$ & $\begin{array}{l}\text { Children develop their willpower, } \\
\text { purposefulness, intellect, } \\
\text { language, communication skills, } \\
\text { awareness of their abilities, } \\
\text { cooperation skills, ability to trust; } \\
\text { they learn to observe the rules of } \\
\text { a game. }\end{array}$ & $\begin{array}{l}\text { Adults set a good example } \\
\text { and participate actively } \\
\text { in children's games. It is } \\
\text { important to understand } \\
\text { the game and respect } \\
\text { children's inner needs and } \\
\text { of a particular age, as well } \\
\text { as to sustain children's joy } \\
\text { of living. }\end{array}$ \\
\hline
\end{tabular}




\begin{tabular}{|c|c|c|}
\hline $\begin{array}{l}\text { Role plays, building } \\
\text { games, } \\
\text { theatrical plays } \\
\text { (play dialogues, } \\
\text { conversations about } \\
\text { mutual relations) }\end{array}$ & $\begin{array}{l}\text { Children develop their creative } \\
\text { abilities, imagination, learn to } \\
\text { make dialogues, gain social } \\
\text { experience, become aware of } \\
\text { themselves as members of a } \\
\text { group, learn to act together, } \\
\text { to defend their rights as well } \\
\text { as to give in, cooperate (in role } \\
\text { selection) which will help them } \\
\text { in the communication process in } \\
\text { future. When taking up a specific } \\
\text { role, sense of responsibility is } \\
\text { evoked stimulating children's } \\
\text { self-confidence. Children can } \\
\text { distinguish real relationships } \\
\text { from those in role plays, therefore } \\
\text { a favourable, understanding and } \\
\text { emphatic attitude towards other } \\
\text { children is developed. }\end{array}$ & $\begin{array}{l}\text { Teachers have to make an } \\
\text { environment suitable for } \\
\text { children's playing needs } \\
\text { and devote their time and } \\
\text { space for creative plays. } \\
\text { The emotional climate } \\
\text { of the group, emphatic } \\
\text { communication between } \\
\text { the teacher and the child, } \\
\text { support, interest and care } \\
\text { about one another are } \\
\text { important factors. } \\
\text { It is necessary to broaden } \\
\text { parent's understanding } \\
\text { about the importance } \\
\text { of plays in encouraging } \\
\text { children's entrepreneurial } \\
\text { skills. One must react to } \\
\text { children's conflicts and find } \\
\text { out their causes. }\end{array}$ \\
\hline $\begin{array}{l}\text { Movement plays, } \\
\text { sports games }\end{array}$ & $\begin{array}{l}\text { Children develop their physical } \\
\text { selves, joy of movement } \\
\text { encourages the development of } \\
\text { self-confidence; children act as a } \\
\text { team, see one another's success } \\
\text { and assess it. } \\
\text { They learn to assess themselves, } \\
\text { notice their own mistakes and } \\
\text { not to blame others for their own } \\
\text { failures. } \\
\text { They show emotions through } \\
\text { activities. By cooperating with } \\
\text { one another, children seek } \\
\text { for solutions in unexpected } \\
\text { situations. }\end{array}$ & $\begin{array}{l}\text { One must be careful when } \\
\text { assessing the results of } \\
\text { the games. Teachers know } \\
\text { children's individual traits } \\
\text { and they set requirements } \\
\text { with regard to each child's } \\
\text { abilities. Timid children are } \\
\text { encouraged to overcome } \\
\text { difficulties; however, } \\
\text { this help should not } \\
\text { interfere with the child's } \\
\text { self-awareness, pride or } \\
\text { independence. }\end{array}$ \\
\hline
\end{tabular}

Observations prove that plays encourage children's entrepreneurial skills even more actively than planned events.

\section{Conclusions}

- Entrepreneurial abilities or entrepreneurial competence is an aggregate of personal abilities and qualities that secures successful entrepreneurship. Entrepreneurial abilities include personal qualities and attitudes, knowledge and skills. 
- Childhood is the most sensitive period in a person's life when the foundation for the individual disposition, self-confidence, value, communication and other systems is laid. In order to encourage entrepreneurial abilities, it is necessary to stimulate the development of children's self-confidence, communication skills and creativity from early childhood as well, as to offer children possibilities to participate in fundraising events.

- During preschool education, playing and games constitute the main type of children's activities (role plays, building games, theatrical plays). This is why using games gives the possibility to develop those personal qualities that are necessary for the encouragement of entrepreneurial competence.

- A game is a creative processing of the experienced impressions. For children to be able to use not only their knowledge and experience but also form an attitude, an environment rich in impulses as well as children's own activities are necessary.

- Self-confidence is one of the major factors that encourages children's development in the preschool period. Playing and the development of selfconfidence are interactive.

- Communicative competence is an important precondition for developing entrepreneurial abilities.

- The level of children's communicative competence is characterised by the ability to understand, listen, hear the peers, comprehend the language, narrate and other skills.

- Adults' respect for children and understanding of the playing process, support and an example set encourage children's cognitive, emotional and social development, foster the development of children's selfconfidence, creative abilities and communicative competence. In order to encourage children's activity while playing, adults should provide a suitable environment and devote time for joining children in their games.

\section{References}

1. Bikse, V. (2009) Pétijumà lietoto terminu skaidrojums [Explanation of Terminology Used]. http://www.politika.lv/temas/fwd_eiropa/17406/ (in Latvian).

2. Dēkenens, K. (1921). Agrā bèrnïba [EarlyChildhood]. Rīga: Kultūras balss [Voice of Culture], 138 lpp. (in Latvian).

3. Dzintere, D., Stangaine, I. (2007). Rotala - bērna dzivesveids [Play as Child's Lifestyle]. Rìga: RaKa, 194 lpp. (in Latvian).

4. Kraminšs, E. (2005). Runas prasme saziñā [Speech Skills in Communication]. Rīga: Turïba, 688 Ipp. (in Latvian).

5. Lieǵeniece, D. (1999). Kopveseluma pieeja audzināšanā [Wholeness Approach to Education]. Rīga: RAKA, 231 Ipp. (in Latvian).

6. Omarova, S. (1998). Cilvēks runā ar cilvēku [A Person Speaks to a Person]. Rīga: SIA 
Kamene, 99 lpp. (in Latvian).

7. Piažē, Ž. (2002). Bèrna intelektuālā attīstība [Child's Intellectual Development]. Rīga: Pētergailis, 320 lpp. (in Latvian).

8. Rodari, Dž. (2009). Fantāzijas gramatika [Grammar of Phantasy]. Rīga: Apgāds Zvaigzne ABC, 175 Ipp. (in Latvian).

9. Romenkova, V. (1997). Rotalu attīstïba [Development of Games]. Rīga: Vārti, 31 lpp. (in Latvian)

10. Stangaine, I. (2010). Pieaugušā un bērna sociālā mijiedarbïba rotaļā - pirmsskolēna komunikatīvās kompetences sekmētāja [Adult - Children Social Interaction in Games as Stimulating Factor of Pre-schoolers' Communicative Competence]. RPIVA V Starptautiskās zinātniskās konferences Teorija praksei mūsdienu sabiedrïbas izglitīiba rakstu krājums [Proceedings of the RTTEMA $5^{\text {th }}$ International Scientific Conference Theory for Practice in the Education of Contemporary Society]. Riga: RPIVA, 312.-317. Ipp. (in Latvian).

11. Students, J. A. (1935). Bèrna, pusaudža un jaunieša psiholoǵija [Child, Teenager and Young Person Psychology]. Rìga: Autora izdevumā, 735 lpp. (in Latvian).

12. Брунер, Дж. (1987). Игра, мышление и речь [Play, Thinking and Speech]. B: Перспективы. Вопросы образования, №. 1 [Perspectives. Issues of Education, No 1]. Москва, c. 73-82. (in Russian).

13. Выготский, Л. (1997). Вопросы детской психологии [lssues of Children Psychology]. Санкт-Петербург: Союз, с. 224. (in Russian).

Assistant Professor Dr. paed., Mg. psych. Agrita Tauriṇa

Riga Teacher Training and Educational Management Academy

Address: Imantas 7. linija 1, Riga, LV-1083, Latvia

Phone: (+371) 26038152

E-mail: rpzaust@tvnet.lv

\section{Lecturer Mg. paed. Inga Stangaine}

Riga Teacher Training and Educational Management Academy

Address: Imantas 7. linija 1, Riga, LV-1083, Latvia

Phone: (+371) 29211579

E-mail: stangaineinga@inbox.lv 